\title{
Pattern and process of vegetation change (succession) on two northern
}

\section{New Zealand island volcanoes}

\author{
Bruce D. Clarkson ${ }^{1}$, Beverley R. Clarkson ${ }^{2}$ and James O. Juvik ${ }^{3}$ \\ ${ }^{1}$ Environmental Research Institute, University of Waikato, Private Bag 3105, Hamilton, New Zealand, (b.clarkson@waikato.ac.nz), \\ ${ }^{2}$ Landcare Research, Private Bag 3127, Hamilton, New Zealand, (clarksonb@landcareresearch.co.nz) \\ ${ }^{3}$ Geography and Environmental Studies, University of Hawai'i-Hilo, Hawaii 96720 USA, (jjuvik@hawaii.edu)
}

\begin{abstract}
Pattern and process of vegetation change (succession) were compared on two northern North Island volcanoes: Whakaari (White Island) and Rangitoto Island where the endemic woody tree Metrosideros excelsa is the primary colonizer of raw volcanic substrates. Quantitative data from our previous publications (see References) and the references therein illustrate sequences of vegetation succession following significant volcanic eruptions. New information on Rangitoto Island $M$. excelsa patch dynamics and updated vascular species statistics for Whakaari have also been included. We also draw on supporting data from $M$. excelsa forest on the mainland and long-inactive volcanic islands in the Bay of Plenty, to provide a context for understanding the vegetation dynamics on Whakaari and Rangitoto Island. Species facilitation, light availability, humidity, substrate and disturbance history are all key determinants of vegetation succession across these volcanic landscapes.
\end{abstract}

\section{INTRODUCTION}

Volcanic activity (including lava flows, debris flows and tephra eruptions) has been a regular feature of many northern New Zealand landscapes, causing long-lasting impacts on the vegetation. Over the last 40 years we have been using a combination of the chronosequence and direct monitoring methodologies (Clarkson 1998; Walker et al. 2010) to research the pattern and process of vegetation change (succession) across young volcanic landscapes (currently active to $<600$ years), and long-inactive volcanoes $(>6000$ years).

\section{Whakaari (White Island)}

Whakaari is a 238 ha island volcano (highest point $321 \mathrm{~m}$ a.s.1.) located $50 \mathrm{~km}$ north of North Island mainland in the Bay of Plenty (Fig. 1). It has been in the state of continuous solfataric activity, with intermittent small steam and tephra eruptions

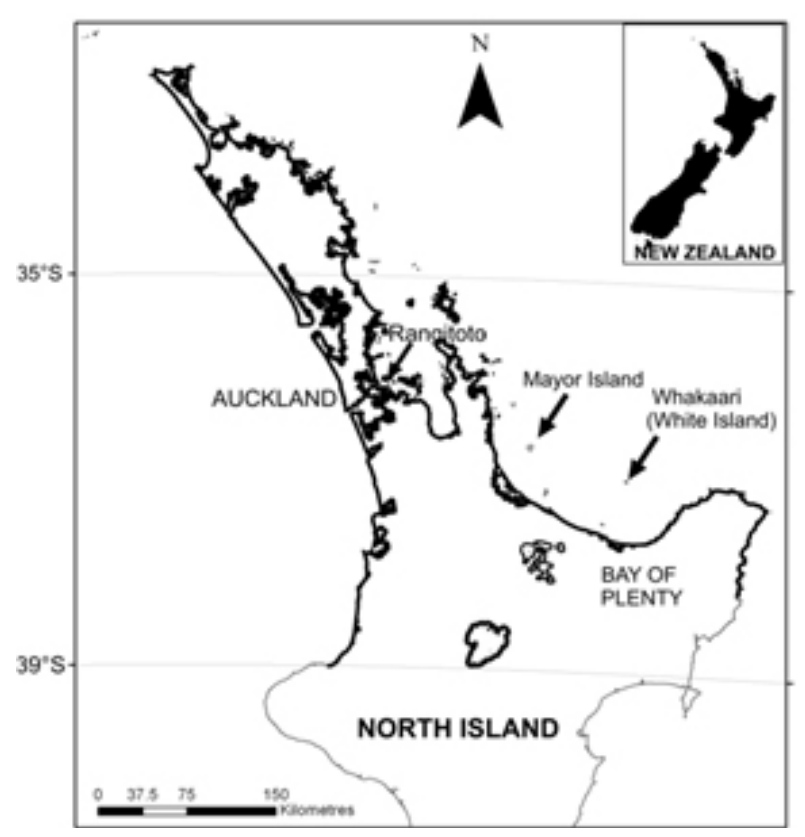

Figure 1: Map showing location of study sites, North Island, New Zealand. Dark line indicates general distribution of Metrosideros excelsa. 
Table 1: Number of vascular taxa recorded on Whakaari (White Island) between 1912 and 2005 based on Oliver (1915), Hamilton (1959), Gillham (1965), Wilcox (1967), Clarkson \& Clarkson 1994, Ecroyd \& Clarkson unpubl. data (2005). * = exotic

\begin{tabular}{ll}
\hline Ferns & \\
\hline 1 & Asplenium northlandicum \\
2 & Histiopteris incisa \\
3 & Paesia scaberula \\
4 & Pteridium esculentum \\
5 & Pteris tremula
\end{tabular}

\section{Dicotyledonous herbs}

\begin{tabular}{ll}
\hline 6 & Cakile maritima subsp. maritima* \\
7 & Chenopodium trigonon subsp. trigonon \\
8 & Cirsium vulgare* \\
9 & Conyza sumatrensis* \\
10 & Coronopus didymus* \\
11 & Disphyma australe subsp. australe \\
12 & Euchiton involucratus \\
13 & Gamochaeta purpurea* \\
14 & Hypochoeris radicata* \\
15 & Jacobaea vulgaris* \\
16 & Lobelia anceps \\
17 & Paronychia brasiliana* \\
18 & Phytolacca octandra* \\
19 & Pseudognaphalium luteoalbum agg. \\
20 & Senecio bipinnatisectus* \\
21 & Senecio sylvaticus* \\
22 & Solanum nigrum* \\
23 & Solanum nodiflorum* \\
24 & Sonchus asper* \\
25 & Stellaria media subsp. media* \\
26 & Symphyotrichum subulatum* \\
Dicotyledonous trees \& shrubs \\
\hline 27 & Coprosma repens \\
28 & Metrosideros excelsa \\
29 & Ozothamnus leptophyllus \\
Monocotyledons & Cortaderia selloana* \\
\hline 30 & Cyperus eragrostis* \\
31 & Lachnagrostis filiformis \\
32 & Phormium tenax \\
33 & Poa anceps subsp. anceps \\
35 & Holcus lanatus $*$ \\
\hline
\end{tabular}

occurring since 1826. In recent times, major damage to the vegetation has resulted from significant and complex eruptive sequences between 1976-1981 and also 1984-1994. Further volcanic unrest began in July 2012 and has continued intermittently to the present day. Eruptive episodes have included explosive ejections of ash and gas emissions, with acid rain also causing death and dieback of $M$. excelsa forest and Disphyma-Chenopodium herbfields. Metrosideros excelsa dominates a floristically depauperate forest community which, in places, comprises only two or three vascular species, namely $M$. excelsa, Histiopteris incisa, and Phormium tenax. The total vascular flora recorded on the island (36; Table 1) between 1912 and 2005 has ranged between seven and thirteen species before 1990, and approximately 33 species in 2005, which reflects the reduction in volcanic activity between these dates. The post-1990 arrivals, however, are mainly exotic dicotyledonous herbs, and $M$. excelsa remains the only tree species present on the island. Metrosideros excelsa is a mass seeder with wind dispersed seed and the ability to recover from canopy damage by epicormic resprouting. Direct succession of $M$. excelsa results from recovery and spread of an existing population or colonization of a newly emplaced surface by $M$. excelsa seed.

\section{Rangitoto Island}

Rangitoto Island, a basalt shield volcano covering 2311 ha and rising to $260 \mathrm{~m}$ a.s.l. is located in the Hauraki Gulf, 8 km north east of Auckland City (Fig. 1). It appears to have been active between $850 \mathrm{AD}$ and $1800 \mathrm{AD}$, with a maximum lava activity around 1300 AD (Robertson 1986). The primary surface is mainly crusty aa basaltic lava but the summit consists of scoria cones. The last lava flows were followed by an emission of ash that filled most of the crevices and shallow hollows. Metrosideros excelsa is the prime lava colonizer and has coalesced to form continuous forest over large areas of the island. We have been monitoring M. excelsa patch establishment and development between 1980 and the present day in permanent plots established by one of us (JOJ). These plots were representative of the most extreme sites of largely un-vegetated aa lava. The number of vascular species is strongly positively correlated with the size of the M. excelsa patch $\left(\mathrm{r}^{2}=\right.$ $0.742 ; \mathrm{n}=80$ ) with $1-4$ species recorded in patches of $<0.1 \mathrm{~m}^{2}$ and $16-19$ species in patches of $>100 \mathrm{~m}^{2}$. Using patch size in six size classes (midpoints $=1$ $\mathrm{m}^{2}, 3 \mathrm{~m}^{2}, 6 \mathrm{~m}^{2}, 12 \mathrm{~m}^{2}, 24 \mathrm{~m}^{2}, 48 \mathrm{~m}^{2}$ ) and frequency of occurrence as a surrogate for age, it is possible to determine the orderly sequential establishment of species. Early establishers include Coprosma robusta, Myrsine australis and Astelia banksii. Middle and late establishers include Pseudopanax 
arboreus, Collospermum hastatum and Asplenium oblongifolium. The fern, Asplenium flaccidum, which is mostly epiphytic on M. excelsa, is one of the last to arrive. Some species fluctuate in their frequency in relation to patch size, for example, Brachyglottis kirkii, Ctenopteris heterophylla, and Asplenium flabellifolium. These are usually patch edge dwellers and are sometimes lost as the M. excelsa canopy expands but may subsequently recolonise the edge of the patch. Metrosideros excelsa facilitates this deterministic establishment pattern by influencing the microclimate of the site. Surface temperature on open lava may exceed $50^{\circ} \mathrm{C}$ whereas in the interior of a large patch or extensive forest, it is less than $25^{\circ} \mathrm{C}$. Relative humidity is less than $40 \%$ on open lava, exceeds $45 \%$ in large patches and is over $55 \%$ in the forest interior.

\section{Comparison with M. excelsa forests elsewhere}

Plant successions on volcanic landscape are extremely variable both in terms of rates of change and the sequence of species establishing. However, comparison of $M$. excelsa forest across young volcanic islands, long-dormant volcanic islands and the mainland illustrates some regularity in the patterns of succession that arise following disturbance. For example, Mayor Island (Tuhua), a dormant (c. 6000 years) volcano situated between Rangitoto and Whakaari c. $27 \mathrm{~km}$ east of the Coromandel Peninsula (Fig. 1), is dominated by M. excelsa forest. The current forest pattern there was likely initiated by Polynesian burning c. 450 BP. Vegetation change in permanent quadrats (1999-2009) shows proliferation of Litsea calicaris and the establishment of
Dysoxylum spectabile and Corynocarpus laevigatus in the forest understory. On the mainland, L. calicaris, D. spectabile, C. laevigatus commonly establish beneath closed canopy $M$. excelsa forest (usually $>50$ years old) and contribute to the replacement of M. excelsa in the canopy after a minimum period of c. 200 years. In contrast Beilschmiedia tawa, the most shade tolerant tree species to establish within M. excelsa forest, is late successional and requires $\mathrm{c}$. 100 years before conditions are suitable for seedling establishment. On Rangitoto Island, $M$. excelsa facilitates the establishment of mid successional species; however their incursion is much slower than on less severe mainland sites and long-dormant volcanoes, where $M$. excelsa forest has largely been initiated by fire. On much older basaltic lava blocks flanking Mt Eden (c. $10 \mathrm{~km} \mathrm{SW}$ of Rangitoto Island, on the mainland), M. excelsa shares dominance with Vitex lucens, L. calicaris, D. spectabile, Alectryon excelsus and Myoporum laetum and this might indicate future trends on Rangitoto.

Light is a key resource controlling plant species colonization of new sites and replacement in forest understories. The shade tolerance of key species in $M$. excelsa forest and scrub has been quantified using hemispherical photography (Bylsma et al. 2014). Light environment occupancy of key canopy species differs significantly $(\mathrm{P}<0.001)$ according to the distribution of understory light environments available. Pioneer and early successional species (e.g., M. excelsa, Myrsine australis, Kunzea ericoides) occupy the higher spectrum of light environments, whereas mid and late successional tree species (e.g., Litsea calicaris, Dysoxylum spectabile,

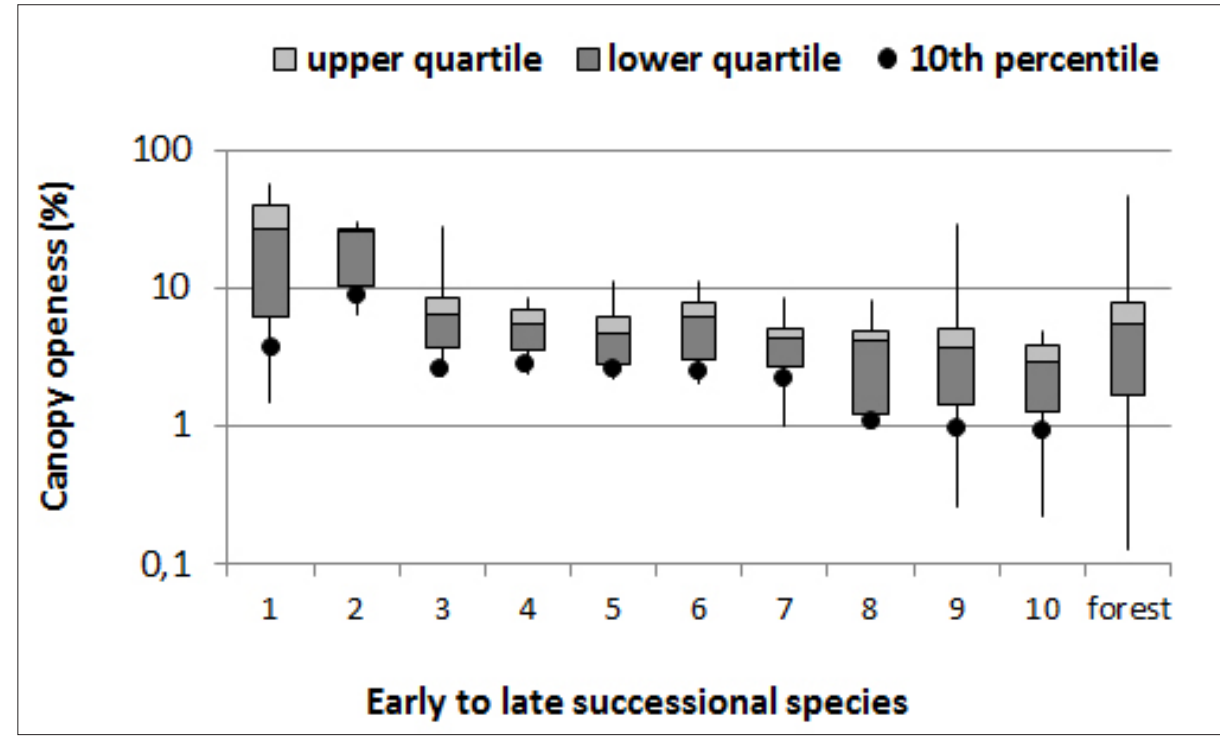

Figure 2: Species light environment distributions: (1) Metrosideros excelsa, (2) Kunzea ericoides, (3) Piper excelsum, (4) Myrsine australis, (5) Geniostoma rupestre, (6) Hedycarya arborea, (7) Dysoxylum spectabile, (8) Corynocarpus laevigatus, (9) Litsea calicaris, (10) Beilschmiedia tawa. Data collected from Ohope Scenic Reserve, Kohi Point Reserve and Matata Scenic Reserve, Bay of Plenty. 
Beilschmiedia tawa) show bias towards the darker microsites (Fig. 2). Ranking species in order of their minimum light requirements (e.g., $10^{\text {th }}$ percentile) approximates their order of arrival in $M$. excelsa forest development.

Comparison of vascular species richness, time since disturbance and island area reveals variable disharmonic floras. On Whakaari, continual volcanic disturbance, isolation and extreme soil conditions have resulted in a depauperate flora (36 spp.) and the simplest $M$. excelsa forest. On Rangitoto Island, the proximity to the mainland, less volcanic disturbance, larger size and relative stability since c. $1800 \mathrm{AD}$ have contributed to a much higher number of species (582 spp.). In addition, the presence of beachside holiday homes since the 1930s has enabled the incursion of numerous exotic species.

\section{ACKNOWLEDGMENTS}

Special thanks for Rebecca Bylsma for allowing us to use her shade tolerance data. We also thank Chris Ecroyd for his contribution to the species list and lodging specimens in the National Forestry herbarium, Rotorua. BR Clarkson was funded in part by the Ministry of Business, Innovation and Employment (Contract C09X0503).

\section{References}

Bylsma R.J.; Clarkson B.D.; Efford J.T. 2014: Biological flora of New Zealand 14: Metrosideros excelsa, pōhutukawa, New Zealand Christmas tree. New Zealand Journal of Botany 52: 365-385.

Clarkson, B.D. 1990: A review of vegetation development following recent $(<450$ years) volcanic disturbance in North Island, New Zealand. New Zealand Journal of Ecology 14: 59-71.

Clarkson, B.D. 2008: Natural history of Rangitoto Island, Hauraki Gulf, Auckland, New Zealand, edited by Mike D Wilcox. New Zealand Journal of Botany 46: 101-104.

Clarkson, B.D., Clarkson, B.R., Smale, M.C. 1989: Appendix 1 Vegetation destruction and recovery following recent eruptions on White Island (Whakaari), Bay of Plenty, New Zealand. In: Houghton, B.F., Nairn; I.A. eds. The 1976-82 eruption sequence at White Island volcano (Whakaari), Bay of Plenty, New Zealand. New Zealand Geological Survey Bulletin 103: 137-138.

Clarkson, B.D.; Clarkson, B.R., 1994: Vegetation decline following recent eruptions on White Island (Whakaari), Bay of Plenty, New Zealand. New Zealand Journal of Botany 32: 21-36.

Gillham, M. E. 1965: A naturalist in New Zealand. Wellington, A.H. \& A.W. Reed

Hamilton, W. M.; Baumgart, I. L. comp. 1959: White Island. DSIR bulletin 127. Wellington, Government Printer.

Oliver, W. R. B. 1915: The vegetation of White Island, New Zealand. Journal of the Linnaean Society of London, botany 43:41-47.

Robertson, D.J. 1986. A paleomagnetic study of Rangitoto Island, Auckland, New Zealand. New Zealand Journal of Geology and Geophysics 29: 405-411.

Walker, L.R.; Clarkson, B.D.; Silvester, W.B.; Clarkson, B.R. 2003: Colonization dynamics and facilitative impacts of a nitrogen-fixing shrub in primary succession. Journal of Vegetation Science 14: 277-290.

Walker, L.R.; Wardle, D.A.; Bardgett, R.D.; Clarkson, B.D. 2010: The use of chronosequences in studies of ecological succession and soil development. Journal of Ecology 98: 725-736.

Wilcox, M. D. 1967: White Island. Auckland Botanical Society Newsletter, April 1967: 6-7. 